\title{
Organometallic Compounds in Drug Discovery: Past, Present and Future
}

\author{
Yih Ching Ong ${ }^{a}$ and Gilles Gasser ${ }^{a}$ *
}

a Chimie ParisTech, PSL University, CNRS, Institute of Chemistry for Life and Health Sciences, Laboratory for Inorganic Chemical Biology, F-75005 Paris, France.

* Corresponding author: Gasser, G. (gilles.gasser@chimieparistech.psl.eu; WWW: www.gassergroup.com; Tel.: +331442756 02).

ORCID-ID:

Yih Ching Ong: 0000-0003-0411-1114

Gilles Gasser: 0000-0002-4244-5097 


\section{Biographies}

Yih Ching Ong completed her PhD studies in 2017 on the solution and solid-state chemistry of anti-leishmanial bismuth complexes under the supervision of Prof. Phil Andrews and Dr. Kellie Tuck in Monash University, Melbourne. She is currently undertaking a post-doctoral fellowship in the group of Prof. Gilles Gasser at Chimie ParisTech, PSL University (Paris, France), synthesising metallocenyl compounds targeted towards parasitic diseases. Her research interests include the development of metal-based complexes for biological applications, and exploring the reactivity of unstable main group metal complexes.

Born, raised and educated in Switzerland, Gilles Gasser performed a $\mathrm{PhD}$ thesis in supramolecular chemistry with Prof. Helen Stoeckli-Evans (University of Neuchâtel, Switzerland) before carrying out two post-docs, first with the late Prof. Leone Spiccia (Monash University, Australia) in bioinorganic chemistry and then as an Alexander von Humboldt fellow with Prof. Nils Metzler Nolte (Ruhr-University Bochum, Germany) in bioorganometallic chemistry. Gilles then started his independent scientific career at the University of Zurich in 2010 first as a Swiss National Science Foundation (SNSF) Ambizione Fellow and then as a SNSF Assistant Professor in 2011. In 2016, Gilles moved to Chimie ParisTech, PSL University (France), thanks among other to a PSL Chair of Excellence Program Grant. Gilles was the recipient of several fellowships and awards including the Alfred Werner Award from the Swiss Chemical Society, an ERC Consolidator Grant, the Thieme Chemistry Journal Award, the Jucker Award for his contribution to cancer research and recently the EuroBIC Medal Award for his work in the field of bioinorganic chemistry. 


\begin{abstract}
In this review, we present an overview of some of the medicinally-relevant organometallic drugs that have been used in the past or that are currently in clinical trials as well as an example of compounds that are currently in the initial stage of drug development. Three main classes of organometallic complexes have been chosen for discussion: antimicrobial organoarsenicals, antimalarial and anticancer ferrocene-containing compounds and anticancer catalytic organometallic complexes. The purpose of this review is to provide readers with a focus on the significant progress that has been made for each of these respective fields of medicine.
\end{abstract}

\title{
Introduction
}

An organometallic complex is generally defined as a metal-containing compound that has at least one direct, covalent metal-carbon bond. ${ }^{1}$ The most prominent examples of this class of compounds are most probably the (half-)sandwich compounds and the transition metal carbenes, with ferrocene and the Grubbs catalysts being typical examples of these two classes of organometallic complexes. Such compounds have found tremendous applications in catalysis or biosensing but, as surprising as it can be for certain readers of this article, also in medicine. ${ }^{2-}$ ${ }^{7}$ At this stage of the review, it is important to highlight that the famous platinum(II) anticancer drugs cisplatin, oxaliplatin and carboplatin, the antiarthritic gold(I) auranofin or the MRI agents based on gadolinium(III) are not organometallic complexes since they do not have a metalcarbon bond - they are defined as coordination complexes.

In this review, we intend to give the readers an overview of the (potential) use of organometallic compounds in medicine. We have chosen a few examples, selected by scientific importance and personal affinity to the field of research, to explain the concepts used so far with such complexes. More specifically, we are discussing below three main classes of medicinallyrelevant organometallic complexes, namely 1) antimicrobial organoarsenicals, 2) antimalarial and anticancer ferrocene-containing compounds and 3) anticancer catalytic organometallic complexes. Importantly, the selected examples include compounds which were or are approved (organoarsenicals), that are currently in (pre-)clinical trials (antimalarial and anticancer ferrocene-containing compounds) or that are, for the moment, at an initial stage of drug development (anticancer catalytic organometallic complexes). We note that we are not discussing herein anticancer $\mathrm{Ru}(\mathrm{II})$-arene complexes since this topic has been extensively reviewed. ${ }^{1,8-10}$ 


\section{Organoarsenicals}

An important structure-activity relationship (SAR) study was performed by Paul Ehrlich and Alfred Bertheim, at the beginning of the $20^{\text {th }}$ century, to find a safer alternative to aminophenyl arsenic acid, also known by its commercial name Atoxyl ${ }^{\circledR}$ (Figure 1), to treat the African sleeping sickness (African trypanosomiasis). ${ }^{11}$ Atoxyl ${ }^{\circledR}$, discovered by the French biologist Pierre Jacques Antoine Béchamp, had to be given in high doses, over a prolonged period, for an effective treatment. However, this treatment was leading to a high risk of blindness due to optic nerve atrophy. Ehrlich and Bertheim therefore undertook an important SAR study to unveil compound No. 418, named Spirasyl® or arsenophenylglycine (Figure 1). This compound, despite having still some side-effects, was employed to treat African sleeping sickness, which had high mortality rates, ${ }^{11}$ as of 1907.

A breakthrough in the fight against syphilis happened in 1905 when Fritz Schaudinn and Erich Hoffmann discovered that the Treponema pallidum spirochete was the causal agent of syphilis. One has to remember that the impact of this disease was comparable to that of AIDS today. Due to the similarity between spirochetes and trypanosomes, Hoffmann advised Ehrlich to employ his series of arsenic compounds to treat patients with syphilis. To do this, Ehrlich capitalized on the discovery of Sahachiro Hata, a Japanese student, who joined Ehrlich's lab. The testing of arsenic compounds on Hata's syphilis infection in rabbits led to the emergence of compound No. 606, namely arspheamine. This was marketed in 1910 by Hoechst under the name Salvarsan ${ }^{\circledR}$, “the arsenic that saves life” (Figure 1). Worthy of note, Salvarsan $®$ was later found to be a mixture of three- and five-membered cyclic compounds by mass spectrometry in 2005 (Figure 1). ${ }^{12}$

The lack of water-solubility of Salvarsan led to the preparation of compound No. 914 or neoarsphenamine (Figure 1), which was marketed in 1914 under the name Neosalvarsan ${ }^{\circledR}$. Interestingly, in 1930, it was discovered that oxophenarsine (marketed under the name Mapharsen ${ }^{\circledR}$, Figure 1) was actually the active metabolite of arsphenamine, which is oxidized upon intravenous injection in patient. Mapharsen ${ }^{\circledR}$, which is stable contrary to arsphenamine, which had to be kept in sealed vials under a nitrogen atmosphere, therefore became the drug used for the treatment of syphilis until penicillin came to the market in 1940. Surprisingly, Mapharsen ${ }^{\circledR}$ was one of the compounds tested by Ehrlich and Hata (compound No. 599) but was dismissed due to its presumably high toxicity. ${ }^{11}$ 
An arseno-bismuth complex, namely Bimarsen ${ }^{\circledR}$ (Figure 1), was employed for the treatment of neurosyphilis due its low toxicity, tonic effect and ease of administration, although relapses were more often encountered, particularly in the central nervous system, than with other organoarsenical complexes. ${ }^{2,13}$ Other arsenic-containing compounds such as Bemarsal ${ }^{2}$, Amibiarson ${ }^{\circledR}$, Stovarsol ${ }^{\circledR}$, Gynoplix ${ }^{\circledR}$ or Collusulfar ${ }^{\circledR}$ (Figure 1) were used to treat infections caused by Entamoeba histolytica (Amebiasis), Trichomonas Vaginalis as well as Vincent's Angina, respectively, with a few of these complexes having been withdrawn from the market only in the 1990 s. ${ }^{2,13}$

These days, arsenic-containing compounds are still being used. $\mathrm{As}_{2} \mathrm{O}_{3}$ (Trisenox ${ }^{\circledR}$ ), which is not an organometallic compound, is currently being employed for the treatment of patients with relapsed acute myeloid leukemia. ${ }^{2,14}$ Melasorprol (Arsobal ${ }^{\circledR}$ ) is still used to treat African sleeping sickness. Although not completely clear, the target of organoarsenical drugs is anticipated to be mitochondrial proteins involved in regulating the production of reactive oxidative species (ROS). Those proteins are inhibited by the disulphide linkage of vicinal thiol groups. This leads to increased ROS production and to induction of apoptotic signalling pathways. ${ }^{15}$ We also note that the mode of action of the approved arsenic-containing drug, $\mathrm{As}_{2} \mathrm{O}_{3}$, was found to be through the promotion of degradation of an oncogenic protein that drives the growth of APL cells, PML-RARa (a fusion protein containing sequences from the PML zinc finger protein and retinoic acid receptor alpha). ${ }^{16}$ For the readers who would like more information on the subject of organo-arsenicals, we invite them to look at different reviews or book chapters. ${ }^{2,11,13,17}$ 




Figure 1

Figure 1. Structures of different arsenic-containing compounds used in medicine. 


\section{Ferrocene-containing Drug Candidates}

In the past few decades, there has been increasing interest in the preparation of drug candidates derived from iron, especially in the form of ferrocene. Ferrocene is a compact metallocene which possesses low toxicity and is stable in non-oxidising environments. Its ability for reversible redox reactions contribute towards its antiparasitic and antitumor activity. In this section, we will touch briefly the history of ferrocenyl analogues, focus on the exciting progress of Ferroquine as an antimalarial candidate, and discuss its repurposing as an anticancer and antihepatitis $\mathrm{C}$ candidate. The anticancer drug candidate ferrocifen family of compounds will also be discussed.

Ferrocerone (Figure 2a) holds the distinction of being the first ferrocene derivative to have been approved for clinical use in 1971 in the former USSR. ${ }^{1}$ It was first prepared by the Russian scientist, Alexander Nikolaevich Nesmeyanov to treat iron deficiency anaemia in children. ${ }^{18}$ The idea was that the lipophilicity of the ferrocene moiety would allow for more effective oral administration, as compared to simple Fe(II) salts such as Ferrum-lek®, an iron(III)-hydroxide polymaltose complex, and Ferrocal ${ }^{\circledR}$, a combination treatment of ferrous citrate and calcium citrate. Although Ferrocerone is no longer available on the market, other ferrocenyl-derived drug candidates carry on the legacy with their success in other areas of disease. ${ }^{19}$

A prime example is the leading drug candidate against malaria, Ferroquine (FQ, SSR97193, Figure 2a). Designed in 1994 in Lille by the Brocard group, FQ is the ferrocene analogue of chloroquine (CQ, Figure 2a), a first-line anti-malarial drug which has issues with resistance due to mass administration programs. Studies showed that FQ was equally active in vitro against both CQ-sensitive and resistant Plasmodum falciparum (more active than CQ against CQresistant strain). This is due to several factors: (i) The ferrocene moiety is located inside the lateral chain, which is key for the antimalarial activity of FQ towards CQ-resistant parasites. (ii) FQ also forms a 1:1 stiochiometric complex with haematin, resulting in the inhibition of $\beta$ hematin formation ( $\mathrm{IC}_{50} 0.8 \mu \mathrm{M}$, vs $\mathrm{CQ}_{\mathrm{IC}} \mathrm{IC}_{50} 1.9 \mu \mathrm{M}$ ). Haematin is a product from the digestion of host-cell haemoglobin. ${ }^{20}$ Haematin is toxic due to its oxidative properties (production of ROS), which can disrupt cell membranes. Parasites can inactivate hematin by converting it to $\beta$-hematin. ${ }^{21}$ (ii) Due to the presence of the ferrocene moiety, FQ is at least 100 times more lipophilic than $\mathrm{CQ}$ at cytosolic $\mathrm{pH} 7.4$, which facilitates transport through the cytosol to the food vacuole ( $\mathrm{pH}$ 5.2), a site within the parasite where FQ is concentrated. (iii) The presence of the redox-active ferrocene moiety allows for the production of DNA-damaging hydroxyl 
radicals in situ from hydrogen peroxide via a Fenton-type reaction. ${ }^{22}$ The levels of reactive oxygen species are low enough to have little effect on the stability of FQ, but high enough to promote significant damage to the membranes of the parasite food vacuole before resistance mechanisms can kick in. ${ }^{22}$ (iv) Furthermore, FQ is able to bypass current resistant mechanisms since the postulated transporter linked to CQ-resistance is extremely specific for CQ. This explainsthe activity of FQ against CQ-resistant strains. No other ferrocene analogues had equal or better anti-malarial activity despite the structure-activity investigation on another 120 ferrocenyl derivatives. After various validations of its specific pharmacology, ${ }^{23,24} \mathrm{FQ}$ entered phase I clinical trials with Sanofi-Aventis in 2003 in Gabon, Senegal, Cambodia, Thailand and Madagascar. ${ }^{24}$ Initially, FQ was used in dual therapy with artesunate (ARS), a semi-synthetic analogue of artemisinin, ${ }^{25}$ the traditional Chinese anti-malarial drug discovered by Tu Youyou (2015 Nobel prize winner in Medicine). FQ/ARS dual therapy was continued in Phase II clinical trials, resulting in high cure rates. ${ }^{26}$ Other studies ${ }^{27}$ were conducted concurrently with monotherapy to measure the pharmacokinetics parameters of FQ. In order to limit the risk of resistance, $\mathrm{FQ} / \mathrm{ARS}$ was switched to a single dose combination therapy of $\mathrm{FQ} / \mathrm{OZ439}$ (artefenomel, a novel synthetic trioxolane) ${ }^{28} \mathrm{FQ}$ allows for long duration of plasma exposure, with activity against $P$. falciparum CQ-resistant parasites, while artefenomel has quick action and is active against artemeisinin-resistant parasites. Phase IIb studies are currently on-going with planned completion date in 2019.

Current antimalarials such as CQ and hydroxychloroquine (HCQ) have also been repurposed ${ }^{29}$ as anti-cancer candidates currently in clinical trials, due to their ability to selectively target autophagic-lysosomal function in cancer in vitro and in vivo. ${ }^{30} \mathrm{FQ}$ was reported to have potent anti-cancer activity. Further investigations by the Biot group showed that FQ was able to induce cancer cell death in vitro and impair prostate tumour growth in vivo. ${ }^{29}$ Similar to CQ's mode of action, FQ is able to accumulate within lysosomes, and deacidify them. FQ downregulates Akt kinase which plays a role in cell proliferation, and hypoxia-inducible factor-1 $\alpha$ (HIF-1 $\alpha$ ), allowing it to be very effective in starved and hypoxic conditions ${ }^{29}$ frequently observed in advanced cancers. FQ induces lysosomal membrane permeabilization, mitochondrial depolarization and caspase-independent cancer cell death. In fact, multiple ferrocenecontaining molecules has been previously reported to have anticancer activity, hence application of ferrocene derivatives in cancer therapy is an active area of research.

On the topic of cancer therapy with metal-based drugs and drug candidates, besides the wellknown platinum and ruthenium complexes cisplatin, oxaliplatin, carboplatin, KP1039, and 
NAMI-A, we must not forget to highlight ferrocifen, a ferrocenyl derivative of Tamoxifen (Figure 2a). Tamoxifen (Nolvadex $\left.{ }^{\circledR}\right)$ is a form of oral chemotherapy used for the prevention and treatment of breast cancer for more than 40 years. ${ }^{31}$ Reviews ${ }^{3,32,33}$ have summarized the mechanisms of action of ferrocifens. The most important point is that the ferrocifens have a different mode of action to the platinum anticancer drugs, targeting proteins rather than DNA bases. For example, three ferrocenophane complexes (Fc-OH-Tam, Fc-diOH and DP1) ${ }^{34}$ show a significant antiproliferative effect on cancer cells, but act via different mechanisms. ${ }^{3}$ These antiproliferative effects appear to be associated with both the redox process of ferrocene, and the formation of the quinone methide $(\mathrm{QM})$. QM is first formed from the phenoxy radical which itself is formed from the redox process involving two electrons and two protons (see mechanism in Fig. 2b). QMs are electrophilic Michael acceptors which reduce quickly upon reaction with nucleophiles like glutathione or nucleobases found in enzymes and DNA. This reduction is usually fatal for the cell.

In vivo studies with $\mathrm{Fc}$-diOH on rats with implanted tumors (9L cells from glioma) have shown that Fc-diOH formulation in lipid nanocapsules $(1 \mathrm{mg} / \mathrm{g}$ or $6.5 \mathrm{mg} / \mathrm{g} \mathrm{Fc}$-diOH in rats quantities of 2.5 or $16.2 \mathrm{mg} / \mathrm{kg}$ for 30 days) led to almost complete elimination of implanted tumors. ${ }^{35}$ This indicates that other targets remain to be found, and that there are applications and mechanistic pathways that have to be further defined.
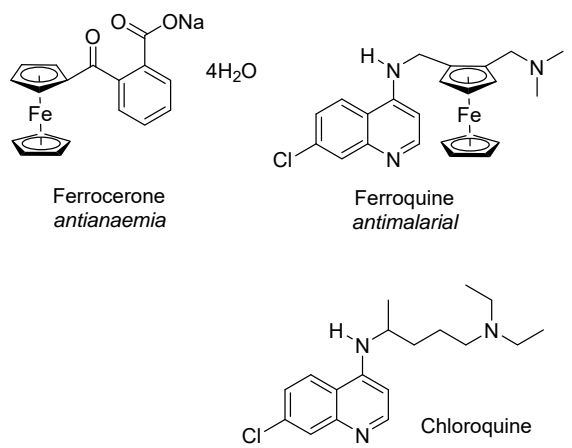
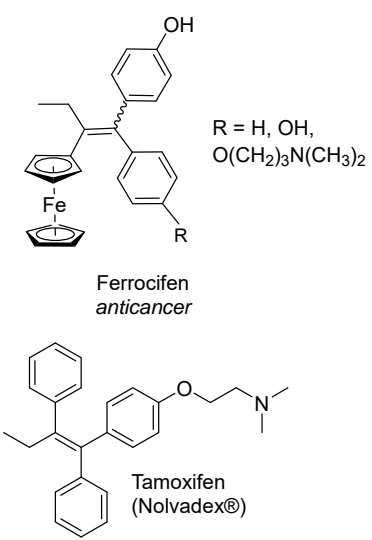

Figure 2 a) Ferrocenyl-containing drugs/drug candidtes and their parent compounds. b)

Mechanism for the formation of quinone methides

\section{Organometallic Compounds as Anticancer Catalytic Drug Candidates}

As mentioned in the introduction, organometallic complexes are notoriously famous for their effectiveness in catalysing a variety of reactions. Over the last years, some of such compounds, namely organometallic $\mathrm{Ru}(\mathrm{II}), \mathrm{Ir}(\mathrm{III})$ and $\mathrm{Os}(\mathrm{II})$ complexes, have also been shown to enable effective killing of cancer cells. ${ }^{36-43}$ This opened up the field of anticancer metallodrug candidates. This new strategy, based on the unique architectures and redox potentials of organometallic compounds, could allow the unveiling of safer metal-based anticancer drug candidates (since lower doses are required) with potentially new modes of actions and overcoming platinum resistance. However, the majority of catalysis does work in organic solution and not in aqueous media in the presence of excess of nucleophiles such as thiols, which can poison the catalyst. Contrary to metalloenzymes, in which metal ions responsible for the catalytic activity are protected within protein cavities, metal centres in small-molecule catalysts are quite exposed to solvent. It was therefore required to develop first biocompatible catalyst for living cells. ${ }^{44-51}$ We note here that the works with nanoparticles by Bradley and Unciti-Broceta are not discussed herein since these are not organometallic compounds. ${ }^{52-54}$

In 2008, the group of Peter Sadler pioneered this field by demonstrating that $\mathrm{Ru}(\mathrm{II})$ arene complexes such as 1 (Scheme 1) containing an iodido ligand (X in Scheme 1) and a $\sigma$-donor/ $\pi$ acceptor phenylazopyridine ligand were stable in aqueous solution but highly cytotoxic to human ovarian A2780 and human lung A549 cancer cells. The observation that the compounds were stable in aqueous solution but were toxic was not fitting with the accepted hypothesis that the halogen ligand(s) of $\mathrm{Ru}(\mathrm{II})$ arene were first exchanged with water before the water molecules will be exchanged with the N7 of guanine or the sulphur atoms of cysteines of proteins or enzymes. The bioactivity of the Ru(II) complex 1 was then explained by its action as a catalyst in reactions with glutathione (GSH, Scheme 1), a strong reducing peptide present in cells at millimolar concentrations. GSH was found to be oxidized to glutathione disulphide (GSSG) in the presence of micromolar ruthenium concentrations, as presented in Scheme 1. Very importantly, since no $\mathrm{H}_{2}$ was detected during the reaction, Sadler and co-workers postulated that the azo $\mathrm{N}=\mathrm{N}$ group was regenerated by concomitant hydrogenation of dissolved $\mathrm{O}_{2}$ to generate $\mathrm{H}_{2} \mathrm{O}_{2}$. This $\mathrm{H}_{2} \mathrm{O}_{2}$ would then be transformed by iodide (displaced from $\mathrm{Ru}$ by the initial substitution reaction with $\mathrm{GSH})$ to $\mathrm{O}_{2}$, explaining the observed gas bubbles $\left(\mathrm{O}_{2}\right){ }^{37}$ 
The generation of reactive oxygen species (ROS) was shown to be responsible for cell death. Indeed, the chloro counterparts of these complexes (i.e. the organometallic complexes with a $\mathrm{Ru}-\mathrm{Cl}$ bond instead of a $\mathrm{Ru}-\mathrm{I}$ ) were found to be much less cytotoxic and to not produce any ROS in living cells. ${ }^{37}$ Worthy of note, cancer cells have a higher basal level of ROS than healthy cells and are therefore more vulnerable to the generation of ROS compared to normal cells. ${ }^{55}$
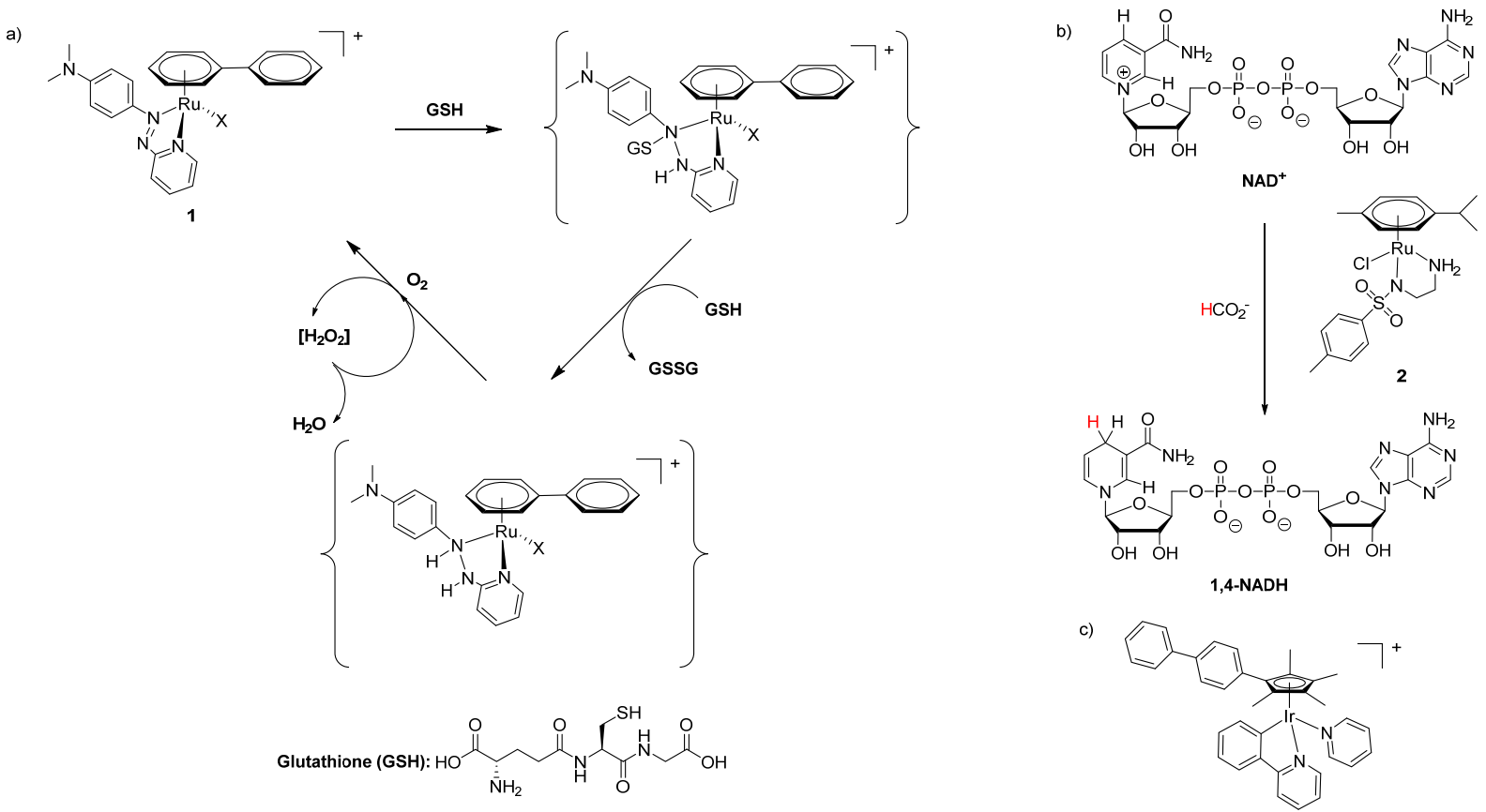

$\mathrm{NAD}^{+}$

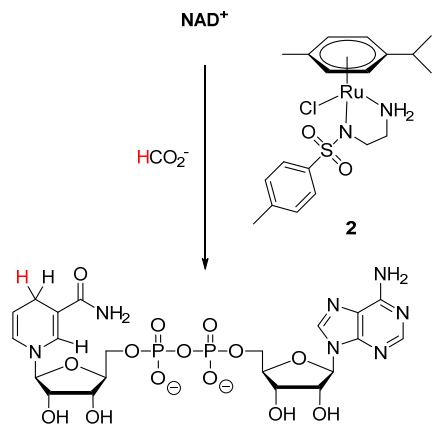

c)

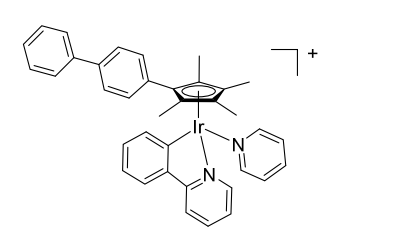

2b

d)
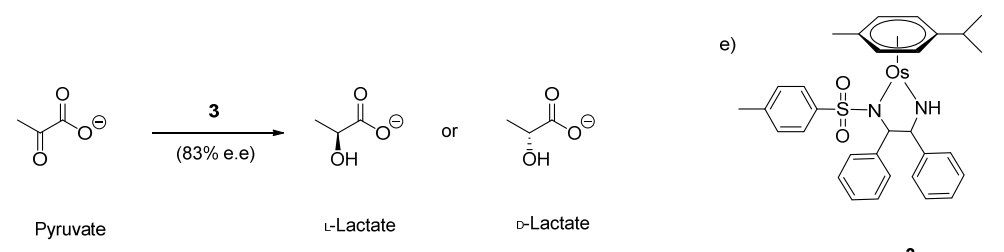

3

Scheme 1 a) Proposed cycle by Sadler and co-workers for the catalytic oxidation of GSH to its corresponding disulfide GSSG by ruthenium(II) arene phenylazopyridine complexes. Initially $\mathrm{X}$ is iodide, which is displaced by $\mathrm{GS}^{-}$during the early stages. Released iodide can catalyze the decomposition of $\mathrm{H}_{2} \mathrm{O}_{2}$. Bound $\mathrm{GSH}$ at $\mathrm{pH} 7$ has deprotonated thiol and carboxyl groups, and a protonated amino group. Scheme adapted from ref. $\left.{ }^{37} \mathbf{b}\right)$ Catalytic conversion of $\mathrm{NAD}^{+}$into 1,4-NADH mediated by formate with a Ru(II) catalyst. Scheme adapted from ref. ${ }^{40}$; c) $\operatorname{Ir}(\mathrm{III})$ organometallic catalyst inducing oxidative stress in cancer cells. $\left.{ }^{38} \mathbf{d}\right)$ Catalytic reduction of pyruvate to lactate in aqueous solution by an Os(II) organometallic complex using formate as a hydride source; e) Structures of an active chiral Os(II) complex $3^{36}$ 
This study was then followed by the first observation of the catalytic reduction of coenzyme $\mathrm{NAD}^{+}$to 1,4-NADH in human ovarian cancer cells in the presence of Noyori-type ruthenium(II) sulfonamido ethyleneamine complexes (2, Scheme 1) using low, non-toxic doses of formate as a hydride donor. ${ }^{40}$ A cytotoxic activity enhancement by up to 14 times in the presence of formate and, very importantly, an increase in selectivity towards cancer cells versus normal cells were observed, thanks to this modulation of the $\mathrm{NAD}^{+} / 1,4-\mathrm{NADH}$ redox couple. The mechanism of cancer cell death was found to involve the generation of reductive stress and not to involve apoptosis or perturbation of mitochondrial membrane potentials. These results were therefore contrasting with the study of the same authors on an organometallic iridium cyclopentadienyl anticancer catalyst, which were inducing oxidative stress ${ }^{38}$ (Scheme 1c for the structure of the Ir(III) complexes). Overall, these two studies clearly confirm the extraordinary ability of organometallic complexes to modulate the redox status of cancer cells. ${ }^{40}$

Very recently, the Sadler group demonstrated that highly stable chiral 16-electron halfsandwich organometallic Os(II) arene sulfonyl diamine complexes (3, Scheme 1) were able to achieve a highly enantioselective reduction of pyruvate, a key intermediate in metabolic pathways, to D-lactate and L-lactate, respectively, in the presence of non-toxic concentrations of sodium formate used as a hydride source in human cancer cells (Scheme 1) $)^{36}$. This work is of high interest since it is based on two key vulnerabilities in cancer cells, namely 1) the high need for glucose for cancer cells resulting in an increased lactate accumulation (i.e. Warburg effect). ${ }^{56}$ Overexpression in cancer cells of lactate dehydrogenase (LDH), which catalyses the interconversion of pyruvate and lactate,${ }^{57}$ is associated to a high likelihood of metastases and a poor clinical prognosis. ${ }^{5,59}$ Therefore, by converting pyruvate into lactate using an artificial catalysts and hydride source, the ability of cancer cells to harness energy and essential metabolites, such as $\mathrm{NAD}^{+}$is threatened; 2) due to their high metabolic demand to satisfy their rapid proliferation, cancer cells are under redox stress. However, cancer cells cannot recover from redox stress and avoid damage since, contrary to healthy proliferating cells, they do not have fully functional mitochondria. ${ }^{59}$ Interestingly, as expected taking into account the rationales of this study just described, the authors could demonstrate selectivity towards ovarian cancer cells versus non-cancerous fibroblasts (both ovarian and lung) of their catalytic system. Interestingly, the authors also investigated the use of formylmethionine as a hydride source since it can release formate when catabolised by the deformylase enzyme, an enzyme overexpressed in certain cancer cells. ${ }^{36}$ In their conclusions, the authors also discussed the 
potential of such discoveries in terms of potential clinical translation. They envisaged a coadministration of the catalyst and the reducing agent using nanoparticle encapsulation or polymeric micelles to solve the problem of the presence of three different chemicals (i.e. substrate, reducing agent and catalyst) to allow for the catalysis to proceed. ${ }^{36}$ 


\section{Concluding remarks}

It is undeniable that organometallic compounds are gaining increasing progress and significance within the field of medicine. Our discussion has traversed across a varied range of studies, from the antimicrobial organoarsenicals prominently used throughout history, to the ferrocene-containing compounds which have been investigated for different diseases such as malaria or cancer. Last but not least, we also covered the anticancer catalytic organometallic complexes, which were represented by the $\mathrm{Ru}(\mathrm{II})$ arenes, the Noyori-type ruthenium(II) sulfonamido ethyleneamines and the Os(II) arene sulfonyl diamines.

\section{Conflicts of interest}

There are no conflicts of interest or disclosures associated with this manuscript.

\section{Acknowledgments}

This work was financially supported by the Swiss National Science Foundation (Grant SNSF Sinergia CRSII5_173718 to G.G.) and has received support under the program Investissements $\mathrm{d}$ Avenir launched by the French Government and implemented by the ANR with the reference ANR10-IDEX-0001-02 PSL (G.G.). 


\section{References}

(1) Gasser, G.; Ott, I.; Metzler-Nolte, N. Organometallic Anticancer Compounds. J. Med. Chem. 2011, 54, 3-25.

(2) Jaouen, G. .; Metzler-Nolte, N. Medicinal Organometallic Chemistry; Jaouen, G., Metzler-Nolte, N., Eds.; Topics in Organometallic Chemistry; Springer Berlin Heidelberg: Berlin, Heidelberg, 2010; Vol. 32.

(3) Jaouen, G.; Vessières, A.; Top, S. Ferrocifen Type Anti Cancer Drugs. Chem. Soc. Rev. 2015, 44, 8802-8817.

(4) Bruijnincx, P. C.; Sadler, P. J. New Trends for Metal Complexes with Anticancer Activity. Curr. Opin. Chem. Biol. 2008, 12, 197-206.

(5) Gasser, G.; Metzler-Nolte, N. The Potential of Organometallic Complexes in Medicinal Chemistry. Curr. Opin. Chem. Biol. 2012, 16, 84-91.

(6) Barry, N. P. E.; Sadler, P. J. 100 Years of Metal Coordination Chemistry: From Alfred Werner to Anticancer Metallodrugs. Pure Appl. Chem. 2014, 86, 1897-1910.

(7) Ronconi, L.; Sadler, P. J. Using Coordination Chemistry to Design New Medicines. Coord. Chem. Rev. 2007, 251, 1633-1648.

(8) Süss-Fink, G. Arene Ruthenium Complexes as Anticancer Agents. Dalt. Trans. 2010, 39, 1673-1688.

(9) Casini, A.; Hartinger, C. G. .; Nazarov, A. A. .; Dyson, P. J. Organometallic Antitumour Agents with Alternative Modes of Action. In Medicinal Inorganic Chemistry; Jaouen, G. ., Metzler-Nolte, N., Eds.; Springer-Verlag Berlin Heidelberg, 2010; Vol. 32, pp 57-80.

(10) Pizarro, A. M.; Habtemariam, A.; Sadler, P. J. Activation Mechanisms for Organometallic Anticancer Complexes. In Medicinal Organometallic Chemistry; Jaouen, G., Metzler-Nolte, N., Eds.; Springer Berlin Heidelberg: Berlin, Heidelberg, 2010; pp 21-56.

(11) Bosch, F.; Rosich, L. The Contributions of Paul Ehrlich to Pharmacology: A Tribute on the Occasion of the Centenary of His Nobel Prize. Pharmacology 2008, 82, 171-179.

(12) Lloyd, N. C.; Morgan, H. W.; Nicholson, B. K.; Ronimus, R. S. The Composition of Ehrlich's Salvarsan: Resolution of a Century-Old Debate. Angew. Chemie - Int. Ed. 2005, 44, 941-944.

(13) Patra, M.; Gasser, G.; Metzler-Nolte, N. Small Organometallic Compounds as Antibacterial Agents. Dalton Trans. 2012, 41, 6350-6358.

(14) Ho, P. C. As Metallotherapeutic Arsenic Compounds. In Metallotherapeutic Drugs \& Metal-based Diagnostic Agents - The Use of Metals in Medicine; Gielen, M. ., Tiekink, E. R. T., Eds.; John Wiley \& Sons, Ltd: Chichester, West Sussex, England, 2005.

(15) Ralph, S. J. Arsenic-Based Antineoplastic Drugs and Their Mechanisms of Action. Met. Based. Drugs 2008, 2008.

(16) Zhang, X. W.; Yan, X. J.; Zhou, Z. R.; Yang, F. F.; Wu, Z. Y.; Sun, H. Bin; Liang, W. X.; Song, A. X.; Lallemand-Breitenbach, V.; Jeanne, M.; et al. Arsenic Trioxide Controls the Fate of the PML-RAR $\alpha$ Oncoprotein by Directly Binding PML. Science 2010, 328, 240-243.

(17) Ni Dhubhghaill, O. M.; Sadler, P. J. The Structure and Reactivity of Arsenic Compounds: Biological Activity and Drug Design. In Bioinorganic Chemistry; Springer Berlin Heidelberg: Berlin, Heidelberg, 1991; pp 129-190.

(18) Chatt, J.; Rybinskaya, M. I. Aleksandr Nikolaevich Nesmeyanov, 9 September 1899 17 January 1980. Biogr. Mem. Fellows R. Soc. 1983, No. 29, 399-480.

(19) O’Connor, J. M. Bioorganometallics: Biomolecules, Labeling, Medicine Edited by 
Gérard Jaouen (Ecole Nationale Supérieure de Chimie de Paris). Wiley-VCH Verlag GmbH \& Co. KGaA: Weinheim. 2006. Xxiii + 444 Pp. \$170.00. ISBN 3-527-30990X. J. Am. Chem. Soc. 2006, 128, 9980.

(20) Hempelmann, E. Hemozoin Biocrystallization in Plasmodium Falciparum and the Antimalarial Activity of Crystallization Inhibitors. Parasitol. Res. 2007, 100, 671-676.

(21) Pagola, S.; Stephens, P. W.; Bohle, D. S.; Kosar, A. D.; Madsen, S. K. The Structure of Malaria Pigment $\beta$-Haematin. Nature 2000, 404, 307.

(22) Osella, D.; Ferrali, M.; Zanello, P.; Laschi, F.; Fontani, M.; Nervi, C.; Cavigiolio, G. On the Mechanism of the Antitumor Activity of Ferrocenium Derivatives. Inorganica Chim. Acta 2000, 306, 42-48.

(23) Dubar, F.; Biot, C. On the Molecular Mechanisms of the Antimalarial Action of Ferroquine. In Bioorganometallic Chemistry: Applications in Drug Discovery, Biocatalysis, and Imaging; Jaouen, G., Salmain, M., Eds.; Wiley-VCH Verlag GmbH \& Co. KGaA, 2015; pp 144-164.

(24) Biot, C.; Nosten, F.; Fraisse, L.; Ter-Minassian, D.; Khalife, J.; Dive, D. The Antimalarial Ferroquine: From Bench to Clinic. Parasite 2011, 18, 207-214.

(25) F, V. Artemisia Annua. 2006, 160-161.

(26) Held, J.; Supan, C.; Salazar, C. L. O.; Tinto, H.; Bonkian, L. N.; Nahum, A.; Moulero, B.; Sié, A.; Coulibaly, B.; Sirima, S. B.; et al. Ferroquine and Artesunate in African Adults and Children with Plasmodium Falciparum Malaria: A Phase 2, Multicentre, Randomised, Double-Blind, Dose-Ranging, Non-Inferiority Study. Lancet Infect. Dis. 2015, 15, 1409-1419.

(27) McCarthy, J. S.; Rückle, T.; Djeriou, E.; Cantalloube, C.; Ter-Minassian, D.; Baker, M.; O’Rourke, P.; Griffin, P.; Marquart, L.; Hooft Van Huijsduijnen, R.; et al. A Phase II Pilot Trial to Evaluate Safety and Efficacy of Ferroquine against Early Plasmodium Falciparum in an Induced Blood-Stage Malaria Infection Study. Malar. J. 2016, 15, 19.

(28) Pomel, S.; Dubar, F.; Forge, D.; Loiseau, P. M.; Biot, C. New Heterocyclic Compounds: Synthesis and Antitrypanosomal Properties. Bioorg. Med. Chem. 2015, 23, 5168-5174.

(29) Kondratskyi, A.; Kondratska, K.; Vanden Abeele, F.; Gordienko, D.; Dubois, C.; Toillon, R. A.; Slomianny, C.; Lemière, S.; Delcourt, P.; Dewailly, E.; et al. Ferroquine, the next Generation Antimalarial Drug, Has Antitumor Activity. Sci. Rep. 2017, 7, 1-15.

(30) Vanhollebeke, B.; Pays, E. The Trypanolytic Factor of Human Serum: Many Ways to Enter the Parasite, a Single Way to Kill: MicroReview. Mol. Microbiol. 2010, 76, 806814.

(31) Clemons, M.; Danson, S.; Howell, A. Tamoxifen ('Nolvadex'): A Review. Cancer Treat. Rev. 2002, 28, 165-180.

(32) Hodík, T.; Lamač, M.; Červenková Št’astná, L.; Cuř́nová, P.; Karban, J.; Skoupilová, H.; Hrstka, R.; Císařová, I.; Gyepes, R.; Pinkas, J. Improving Cytotoxic Properties of Ferrocenes by Incorporation of Saturated N-Heterocycles. J. Organomet. Chem. 2017, 846, 141-151.

(33) Bruyère, C.; Mathieu, V.; Vessières, A.; Pigeon, P.; Top, S.; Jaouen, G.; Kiss, R. Ferrocifen Derivatives That Induce Senescence in Cancer Cells: Selected Examples. J. Inorg. Biochem. 2014, 141, 144-151.

(34) Patra, M.; Gasser, G. The Medicinal Chemistry of Ferrocene and Its Derivatives. Nat. Rev. Chem. 2017, 1, 0066.

(35) Vessières, A. Metal Carbonyl Tracers and the Ferrocifen Family: Two Facets of Bioorganometallic Chemistry. J. Organomet. Chem. 2013, 734, 3-16. 
(36) Coverdale, J. P. C.; Romero-Canelón, I.; Sanchez-Cano, C.; Clarkson, G. J.;

Habtemariam, A.; Wills, M.; Sadler, P. J. Asymmetric Transfer Hydrogenation by Synthetic Catalysts in Cancer Cells. Nat. Chem. 2018, 10, 347-354.

(37) Dougan, S. J.; Habtemariam, A.; McHale, S. E.; Parsons, S.; Sadler, P. J. Catalytic Organometallic Anticancer Complexes. Proc. Natl. Acad. Sci. 2008, 105, 11628 11633.

(38) Liu, Z.; Romero-Canelõn, I.; Qamar, B.; Hearn, J. M.; Habtemariam, A.; Barry, N. P. E.; Pizarro, A. M.; Clarkson, G. J.; Sadler, P. J. The Potent Oxidant Anticancer Activity of Organoiridium Catalysts. Angew. Chemie - Int. Ed. 2014, 53, 3941-3946.

(39) Soldevila-Barreda, J. J.; Sadler, P. J. Approaches to the Design of Catalytic Metallodrugs. Curr. Opin. Chem. Biol. 2015, 25, 172-183.

(40) Soldevila-Barreda, J. J.; Romero-Canelón, I.; Habtemariam, A.; Sadler, P. J. Transfer Hydrogenation Catalysis in Cells as a New Approach to Anticancer Drug Design. Nat. Commun. 2015, 6.

(41) Rebelein, J. G.; Ward, T. R. In Vivo Catalyzed New-to-Nature Reactions. Curr. Opin. Biotechnol. 2018, 53, 106-114.

(42) Yang, L.; Bose, S.; Ngo, A. H.; Do, L. H. Innocent But Deadly: Nontoxic Organoiridium Catalysts Promote Selective Cancer Cell Death. ChemMedChem 2017, 12, 292-299.

(43) Witczak, Z. J.; Bielski, R. Coupling and Decoupling of Diverse Molecular Units in Glycosciences; 2017.

(44) Lo, H. C.; Buriez, O.; Kerr, J. B.; Fish, R. H. Regioselective Reduction of NAD+ Models with [Cp*Rh(Bpy)H]: Structure-Activity Relationships and Mechanistic Aspects in the Formation of the 1,4-NADH Derivatives. Angew. Chem. Int. Ed 1999, 38, 1429-1432.

(45) Samsal, P. K.; Streu, C. N.; Meggers, E. Metal Complex Catalysis in Living Biological Systems. Chem. Commun. 2013, 49, 1581-1587.

(46) Dörr, M.; Meggers, E. Metal Complexes as Structural Templates for Targeting Proteins. Curr. Opin. Chem. Biol. 2014, 19, 76-81.

(47) Ngo, A. H.; Bose, S.; Do, L. H. Intracellular Chemistry: Integrating Molecular Inorganic Catalysts with Living Systems. Chem. - A Eur. J. 2018, 1-12.

(48) Streu, C.; Meggers, E. Ruthenium-Induced Allylcarbamate Cleavage in Living Cells. Angew. Chemie - Int. Ed. 2006, 45, 5645-5648.

(49) Patra, M.; Gasser, G. Organometallic Compounds: An Opportunity for Chemical Biology? ChemBioChem 2012, 13, 1232-1252.

(50) Schwizer, F.; Okamoto, Y.; Heinisch, T.; Gu, Y.; Pellizzoni, M. M.; Lebrun, V.; Reuter, R.; Köhler, V.; Lewis, J. C.; Ward, T. R. Artificial Metalloenzymes: Reaction Scope and Optimization Strategies. Chem. Rev. 2018, 118, 142-231.

(51) Sánchez, M. I.; Penas, C.; Vázquez, M. E.; Mascareñas, J. L. Metal-Catalyzed Uncaging of DNA-Binding Agents in Living Cells. Chem. Sci. 2014, 5, 1901-1907.

(52) Weiss, J. T.; Dawson, J. C.; Macleod, K. G.; Rybski, W.; Fraser, C.; Torres-Sánchez, C.; Patton, E. E.; Bradley, M.; Carragher, N. O.; Unciti-Broceta, A. Extracellular Palladium-Catalysed Dealkylation of 5-Fluoro-1-Propargyl-Uracil as a Bioorthogonally Activated Prodrug Approach. Nat. Commun. 2014, 5.

(53) Rubio-Ruiz, B.; Weiss, J. T.; Unciti-Broceta, A. Efficient Palladium-Triggered Release of Vorinostat from a Bioorthogonal Precursor. J. Med. Chem. 2016, 59, 9974-9980.

(54) Weiss, J. T.; Dawson, J. C.; Fraser, C.; Rybski, W.; Torres-Sánchez, C.; Bradley, M.; Patton, E. E.; Carragher, N. O.; Unciti-Broceta, A. Development and Bioorthogonal Activation of Palladium-Labile Prodrugs of Gemcitabine. J. Med. Chem. 2014, 57, 5395-5404. 
(55) Trachootham, D.; Alexandre, J.; Huang, P. Targeting Cancer Cells by ROS-Mediated Mechanisms: A Radical Therapeutic Approach? Nat. Rev. Drug Discov. 2009, 8, 579.

(56) Hirschhaeuser, F.; Sattler, U. G. A.; Mueller-Klieser, W. Lactate: A Metabolic Key Player in Cancer. Cancer Res. 2011, 71, 6921-6925.

(57) Doherty, J.; Cleveland, J. Targeting Lactate Metabolism for Cancer Therapeutics. $J$. Clin. Invest. 2013, 123, 3685-3692.

(58) Koukourakis, M. I.; Giatromanolaki, A.; Winter, S.; Leek, R.; Sivridis, E.; Harris, A. L. Lactate Dehydrogenase 5 Expression in Squamous Cell Head and Neck Cancer Relates to Prognosis Following Radical or Postoperative Radiotherapy. Oncology 2009, 77, 285-292.

(59) Koukourakis, M. I.; Giatromanolaki, A.; Sivridis, E.; Bougioukas, G.; Didilis, V.; Gatter, K. C.; Harris, A. L. Lactate Dehydrogenase-5 (LDH-5) Overexpression in NonSmall-Cell Lung Cancer Tissues Is Linked to Tumour Hypoxia, Angiogenic Factor Production and Poor Prognosis. Br. J. Cancer 2003, 89, 877-885. 